\title{
Earnings Announcements and Investor Focus in the Hospitality Industry
}

Cornell Hospitality Quarterly

2015, Vol. 56(I) 5-16

(c) The Author(s) 2014

Reprints and permissions:

sagepub.com/journalsPermissions.nav DOI: $10.1177 / 1938965513516826$

cqx.sagepub.com

(S)AGE

\author{
Pamela C. Moulton' and Sarah Leow'
}

\begin{abstract}
This study examines how the release of multiple firms' earnings announcements on the same day combines with human attention constraints to affect the trading of hospitality stocks. We document two opposing effects. We find that a rush of earnings announcements from nonhospitality firms leads to investor distraction and reduces the reaction of hospitality stocks to earnings news. Conversely, we find that multiple announcements by firms within the hospitality sector lead to increased investor focus and larger hospitality stock reactions to news. Our results show that multiple announcements can either diminish or enhance investors' reactions to company news, which directly affects the incorporation of new information into hospitality stock prices.
\end{abstract}

\section{Keywords}

investor distraction, hospitality stocks, earnings announcements, market efficiency

A stock's trading volume and price often change significantly when the quarterly earnings announced by a firm's executives are different from what stock analysts and investors expect. For example, when Wyndham Worldwide reported first-quarter 2009 earnings above expectations, its stock price rose more than 30 percent amid high trading volume; a week later, Einstein Noah Restaurant Group reported lower than expected earnings and its stock price fell more than 14 percent, also with heavy trading volume. In recent years, the proportion of stock-price-relevant information contributed by earnings announcements has risen (Ball and Shivakumar 2008). With most of the thousands of publicly traded firms announcing their earnings within a few weeks each quarter ("earnings season"), there is a heavy load of new information for investors to consider.

In this paper, we examine how human attention constraints affect the trading and pricing of hospitality stocks when multiple firms release their earnings announcements on the same day. Our test uses a thirteen-year panel of earnings announcements to study two potential effects of the heavy information load during earnings season, namely, investor focus and investor distraction. With regard to investor focus, we examine whether multiple earnings announcements from hospitality firms on the same day attract investor focus to the hospitality sector, thereby increasing investors' reactions to earnings surprises. This is the first study to our knowledge to test for an investor focus effect from competing firms' announcements. Regarding investor distraction, we examine the potential distracting effects arising from earnings announcements by firms from other industries, which may lead the stocks of hospitality firms to underreact to firm-specific information on days with many nonhospitality earnings announcements. Investor distraction has been documented in the finance literature, but no study to date has considered the possibility of investor focus arising from multiple earnings announcements within a specific industry. Our study thus closes a gap in the literature and provides valuable information for hospitality investors and executives.

Classic efficient-market theory assumes that rational economic agents are able to immediately understand and act on all information about a firm, so stock prices immediately reflect all new information. The idea that human attention or cognitive constraints may affect stock prices originates in the psychology literature. Psychologists have amassed extensive evidence that humans find it hard to perform multiple tasks or process multiple pieces of information at the same time (e.g., Busemeyer, Myung, and McDaniel 1993). In financial markets, theoretical models predict that a heavier information load (such as may arise from multiple firms announcing earnings on the same day) leads investors to underreact to salient news (e.g., Hirshleifer and Teoh 2003). Consistent with this investor-distraction hypothesis, studies of the broad stock market find that trading volume and price reactions to a firm's news are muted when multiple firms announce news on the same day.

'Cornell University School of Hotel Administration, Ithaca, NY

Corresponding Author:

Pamela C. Moulton, Cornell University School of Hotel Administration, 435A Statler Hall, Ithaca, NY 14853, USA.

Email: pmoulton@cornell.edu 
Our focus on hospitality stocks is an important feature of this study because our goals are to develop information of use to hospitality investors and executives as well as to explore the broader question of how human attention constraints affect stock trading. Research on hospitality stocks shows that the hospitality sector differs in potentially important ways from the broad stock market. For example, Weinbaum (2009) finds that restaurant and hotel firms are particularly strategic about when they issue and retire equity capital. If hospitality executives are also more strategic in timing their earnings announcements, it is not obvious that even the investor distraction results documented for the stock market as a whole will hold in the hospitality sector, and no studies have looked at investor focus before. Additionally, Canina (1996) finds that first-day and first-year returns for hospitality initial public offerings exceed those of other firms, suggesting that in some cases investors enjoy unusual advantages in hospitality stocks. These and other studies suggest that findings from studies based on the broad stock market may not apply directly to hospitality stocks.

This study presents direct empirical evidence that when many firms from outside the hospitality sector announce earnings on the same day as a hospitality firm, investors underreact to salient information about the hospitality firm. In contrast, we document that multiple earnings announcements within the hospitality sector actually sharpen investor focus and lead to larger stock price reactions. Announcements from more similar firms appear to aid investor focus and interpretation, rather than distracting from their news. This effect is strongest when announcements come from stocks in the same hospitality subsector, for example, several hotels or restaurants. More generally, our study sheds light on the dual ways that apparently "distracting" information can enhance as well as detract from decision making.

Our findings have important implications for hospitality investors and executives. Hospitality stock investors would be well advised to watch the quarterly earnings calendar not only for the dates on which particular hospitality stocks announce earnings but also for when there will be an unusually large number of nonhospitality or other hospitality stock announcements. Likewise, executives of hospitality firms may benefit from considering how crowded the earnings calendar is before choosing a specific day on which to announce their earnings. ${ }^{1}$ We discuss these and other implications in greater detail at the end of this paper.

\section{Background and Hypotheses}

\section{Psychological Basis for Investor Distraction}

The difficulty humans have in simultaneously processing multiple sources of information or performing multiple tasks is well documented in the psychology literature. In the famous Stroop task (Stroop 1935), people take longer to name the color in which a word is printed when the word itself is the name of a different color (e.g., the word "green" printed in red ink). Studies of dichotic listening, in which subjects are asked to pay attention to two aural messages at the same time, show that people also have trouble processing two stimuli at the same time (e.g., Cherry 1953). Studies of subjects exposed to multiple cues to forecast a variable over time suggest that people have more difficulty attending to multiple pieces of information and filtering out irrelevant cues (e.g., Busemeyer, Myung, and McDaniel 1993).

Research on attention constraints in financial markets finds that investors' limited attention may affect their behavior in several ways. Sims (2003) argues that the inability of otherwise rational economic agents to process all available information leads them to underreact to new information. Peng (2005) predicts that investors who have limited time and attention rationally allocate their information capacity across stocks, leading them to underreact to salient news on days with a heavy information load. Hirshleifer and Teoh (2003) and DellaVigna and Pollet (2009) predict that investors' failure to fully incorporate public information can lead to mispricing. Empirically, Hirshleifer et al. (2004) find that predictability in long-run stock returns arises from traders' neglecting information regarding firms' cash profitability. Several empirical studies provide evidence of the effects of traders' limited attention on stock prices. Hirshleifer, Lim, and Teoh (2009) find that stock prices underreact to news on days with a heavy information load overall. Chakrabarty and Moulton (2012) find that even market makers, who are each responsible for only a small portfolio of stocks, are distracted when other stocks in their portfolio announce earnings. All of these studies examine the distracting effects of a heavy information load, without considering the possible offsetting effect of extraneous information to bring focus to a firm or sector.

Studies suggesting that extraneous information can increase investor focus are less numerous and tend to examine one stock rather than an industry or subsector. Barber and Odean (2008) find that individual investors are net buyers of attention-grabbing stocks, arguing that this effect arises because investors tend to trade whatever draws their attention. Huberman and Regev (2001) find that even stale news (e.g., the accidental re-publication of old news) can induce abnormal trading in a stock. We extend this intuition to a situation where new information is released to examine whether the net effect on investors is to bring focus to other stocks in the same sector, which is an open question.

Our study uses the number of other firms making earnings announcements as a measure of extraneous news that may affect investors' reaction to a particular hospitality firm's earnings announcement. ${ }^{2}$ We focus on the differential effects of earnings announcements from other industries, which are likely to distract investors, versus those from the hospitality industry, which could lead to increased investor 
focus and a richer information environment. Focusing on hospitality stocks allows us not only to shed light on a particular industry of interest but also to examine finer distinctions in the degree of relatedness between hospitality stocks from the same or different hospitality subsectors, as outlined below.

\section{Investor Types: Institutions versus Individuals}

Investors are typically characterized as falling into two groups: institutional investors (such as mutual funds and pension funds, who manage investments professionally) and individual investors (also known as retail investors, who manage only their own personal investments). A natural question is whether we expect attention constraints to affect only one type of investor or both types. In particular, since institutional investors are widely estimated to account for more than 90 percent of stock trading in recent years, if attention constraints are a problem only for individual investors but not for institutional investors, attention constraints are unlikely to affect aggregate trading volume and stock prices in noticeable ways. We observe only aggregate trading volume and stock prices, not the separate trading activity of institutions versus individuals. Fortunately, for this study, research suggests that institutional investors are just as subject to attention constraints (which may also be thought of as time constraints) as are individual investors. For example, Chakrabarty and Moulton (2012) and Corwin and Coughenour (2008) find that even New York Stock Exchange specialists (market makers who are considered among the most sophisticated of institutional traders) are subject to attention constraints. We note that attention constraints are not generally considered behavioral biases, most of which have been documented among individual but not institutional investors. For example, Shefrin and Statman (1985) document the disposition effect (investors' tendency to sell winners and hold onto losers) among individual investors, a bias that is not evident among institutional investors (Chakrabarty, Moulton, and Trzcinka 2013). Attention constraints, in contrast, appear to be not a behavioral bias but rather simply the result of humans' difficulty in processing multiple sources of information simultaneously. As a rational reaction to information overload rather than a behavioral bias, we expect that attention constraints could affect both institutional and individual investors.

\section{Hypotheses}

The main questions we address in this paper are related to whether the release of multiple firms' earnings announcements on the same day distracts investors or increases their focus on hospitality stocks and whether this distraction or focus affects stocks' reactions to earnings surprises. Our null hypothesis is that hospitality investors are sufficiently skilled and motivated to pay attention to and correctly interpret earnings information about a stock regardless of whether other firms announce earnings on the same day. This may occur if, for example, investors in hospitality stocks tend to be highly specialized and thus unlikely to be distracted by other stocks' earnings announcements. Under the null hypothesis, we should find no relation between the number of other earnings announcements and a stock's volume or price reaction on its own earnings announcement day.

Our first alternative hypothesis is that hospitality investors are distracted by other stocks' earnings announcements competing for their attention. This prediction stems directly from the findings in psychology that extraneous information distracts people and reduces their ability to process and act on salient information. Under this hypothesis, more announcements on the same day would interfere with investors' ability to properly interpret and fully react to a hospitality stock's earnings announcement, depressing trading volume and reducing the price reaction to earnings surprises.

Our second alternative hypothesis is that it matters what type of firms announce their earnings on the same day as a particular hospitality stock. Specifically, we predict that earnings announcements by firms outside the hospitality industry would be a source of distraction (leading to lower volume and muted price reactions), while announcements by other hospitality firms would increase investor focus on the hospitality stock of interest. This prediction stems from a closer consideration of which earnings announcements are truly "extraneous" in our context. Earnings announcements from firms in other industries are likely extraneous, distracting potential hospitality investors from a hospitality firm's earnings announcements. In contrast, earnings announcements from other hospitality firms may draw more investor attention to the industry or provide a richer information environment, creating focus on a hospitality firm's announcement rather than distraction from it. Under this hypothesis, more earnings announcements from firms in the hospitality industry would lead to higher volume and a larger price reaction for a hospitality stock. This effect may also occur on a more granular level: earnings announcements from within the same hospitality subsector should be more consequential for a stock's volume and price than those from other hospitality subsectors.

\section{Sample and Data}

Our analysis uses earnings announcements and analyst forecast data for 1999 through 2011 from the Thomson Financial Institutional Brokers Estimate System (I/B/E/S) database, which contains a comprehensive listing of earnings announcements information for publicly traded U.S. firms. We also collect stock price, volume, return, market capitalization, and value-weighted market return for the same years from the Center for Research in Securities 
Exhibit 1:

Descriptive Statistics for Sample Stocks.

\begin{tabular}{|c|c|c|c|}
\hline Panel A: Firms in Sample & M & Median & $S D$ \\
\hline Market capitalization ( $\$$ bn) & 2.48 & 0.54 & 7.08 \\
\hline $\begin{array}{l}\text { Daily trading volume } \\
\text { (shares } \mathrm{mn} \text { ) }\end{array}$ & 1.04 & 0.30 & 2.02 \\
\hline Price $(\$)$ & 22.35 & 16.31 & 31.50 \\
\hline $\begin{array}{l}\text { Number of earnings } \\
\text { announcements }\end{array}$ & 23.3 & 20.0 & 15.1 \\
\hline $\begin{array}{l}\text { Panel B: Hospitality Firms by } \\
\text { Subsector }\end{array}$ & & No. Firms & $\%$ of Sample \\
\hline Restaurants & & 85 & 53.5 \\
\hline Hotels & & 37 & 23.3 \\
\hline Airlines & & 23 & 14.5 \\
\hline Gaming & & 10 & 6.3 \\
\hline Amusement parks & & 4 & 2.5 \\
\hline Total & & 159 & 100.0 \\
\hline
\end{tabular}

Note. The sample includes 159 hospitality stocks from 1999 through 20II. In Panel A, the average market capitalization, daily trading volume, and price and the total number of earnings announcements are calculated for each stock over the sample period, and across-stock statistics are reported.

Prices (CRSP) database, which contains data about all publicly traded U.S. firms. The thirteen-year sample period is chosen to obtain a large enough sample to achieve statistical power.

\section{Sample Selection}

To construct our sample of hospitality firms, we begin by identifying in CRSP all of the U.S. publicly traded firms that belong to the Standard Industry Classification (SIC) codes that are most closely associated with the hospitality sector. We used a broad definition of the hospitality industry to gain statistical power, including restaurants, hotels, airlines, gaming firms, and amusement parks. The individual subsectors (such as restaurants or hotels) contain too few firms to allow us to make clear statistical inferences. The final set of 159 companies is determined by comparing the list of publicly traded hospitality firms with the record of earnings announcements from $\mathrm{I} / \mathrm{B} / \mathrm{E} / \mathrm{S}$, retaining only those hospitality firms for which $\mathrm{I} / \mathrm{B} / \mathrm{E} / \mathrm{S}$ contains earnings announcements and consensus analyst forecasts.

The hospitality sample stocks are typically large, with an average market capitalization of $\$ 2.48$ billion and average daily trading volume of over one million shares (as shown in Exhibit 1, Panel A). More than half the sample stocks are restaurants, and hotels are about one-quarter of the stocks (Exhibit 1, Panel B). The number of earnings announcements varies by stock for two main reasons. First, some stocks are publicly traded for only a part of our sample period. ${ }^{3}$ Second, our sample is restricted to those earnings
Exhibit 2:

Earnings Announcements by Month in Quarter.

\begin{tabular}{lrrrr}
\hline & $\begin{array}{c}\text { First } \\
\text { Month }\end{array}$ & $\begin{array}{c}\text { Second } \\
\text { Month }\end{array}$ & $\begin{array}{r}\text { Third } \\
\text { Month }\end{array}$ & $\begin{array}{c}\text { All } \\
\text { Months }\end{array}$ \\
\hline Hospitality & & & & \\
$\quad$ Restaurants & 836 & 913 & 323 & 2,072 \\
Hotels & 441 & 350 & 112 & 903 \\
Airlines & 246 & 148 & 32 & 426 \\
$\quad$ Gaming & 98 & 91 & 22 & 211 \\
$\quad$ Amusement parks & 12 & 81 & 4 & 97 \\
Total hospitality & 1,633 & 1,583 & 493 & 3,709 \\
Total nonhospitality & 252,930 & 205,121 & 66,741 & 524,792 \\
Total hospitality and & 254,563 & 206,704 & 67,234 & 528,501 \\
nonhospitality & & & & \\
\hline
\end{tabular}

Note. The table contains the number of earnings announcements in each category that are reported in the relevant month of the quarter: First Month includes January, April, July, and October; Second Month includes February, May, August, and November; and Third Month includes March, June, September, and December.

announcement dates on which $\mathrm{I} / \mathrm{B} / \mathrm{E} / \mathrm{S}$ contains a consensus analyst forecast so that the earnings surprise (if any) can be calculated.

\section{Earnings Announcement Dates}

According to the $\mathrm{I} / \mathrm{B} / \mathrm{E} / \mathrm{S}$ database, these hospitality stocks have a total of 3,709 earnings announcements during our sample period. The nonhospitality firms in the database have 524,792 earnings announcements during the sample period. In recent years, the increase in the number of earnings announcements being released after the stock market closes for the day has shifted much of the earnings-related trading activity to the following trading day, so we designate both the day reported in $\mathrm{I} / \mathrm{B} / \mathrm{E} / \mathrm{S}$ and the following trading day as earnings announcement dates.

Exhibit 2 provides a first look at the extent to which hospitality and nonhospitality firms' earnings announcements tend to cluster in time. The table shows the distribution of earnings announcements by month in the quarter; for example, the column labeled "first month" summarizes the number of earnings announcements made in January, April, July, and October for each hospitality subsector and for all other (nonhospitality) sectors. Even at this coarse level, it is clear that earnings announcements tend to cluster in time, with more announcements occurring in the first and second months of the quarter and far fewer occurring in the last month of the quarter. Exhibit 3 presents a closer look at the clustering of earnings announcements, focusing on the fourth-quarter of 2010 as an example (other quarters yield similar profiles). The bars in the top graph represent the number of nonhospitality firms announcing earnings each day, and the bars in the bottom graph represent the number of hospitality firms announcing earnings each day. The 


\section{Exhibit 3:}

\section{Distribution of Earnings Announcements in a Sample Quarter.}

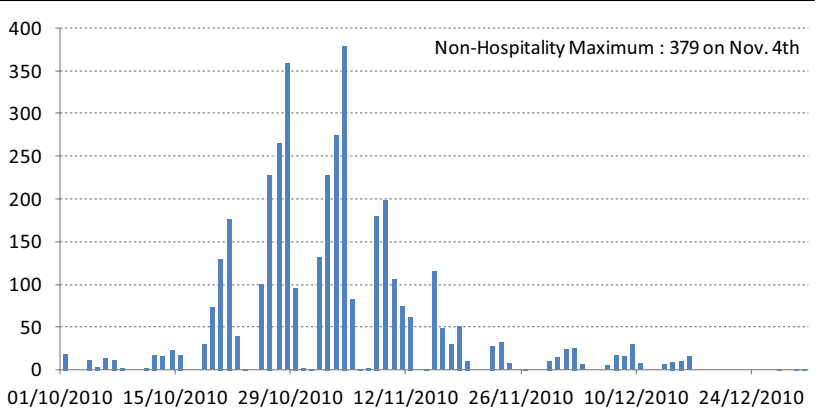

(A)

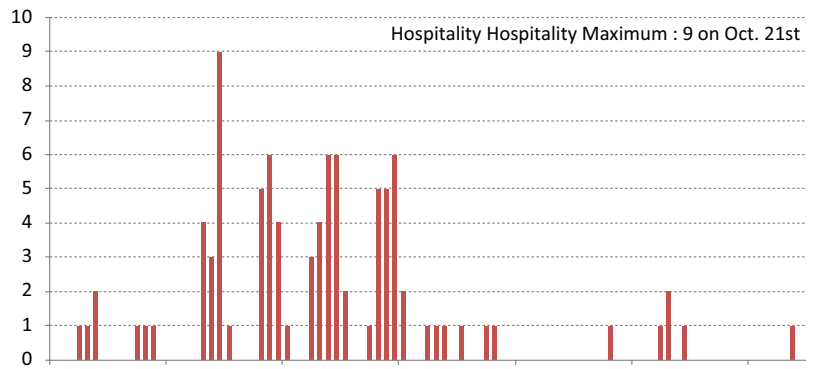

01/10/2010 15/10/2010 29/10/2010 12/11/2010 26/11/2010 10/12/2010 24/12/2010

(B)

(A) Number of nonhospitality earnings announcements per day, October to December 2010. (B) Number of hospitality earnings announcements per day, October to December 2010.

peak period for earnings announcements tends to occur between the middle of the first month (in this example, October) and the middle of the second month (in this example, November) of the quarter. In this particular quarter, the peak occurred on November 4, when 379 nonhospitality firms and six hospitality firms announced their earnings.

In Exhibit 4, we calculate descriptive statistics for the number of earnings announcements occurring on the same day as hospitality stocks' earnings announcements, broken into categories that will be useful in our analyses. The majority of earnings announcements that occur on the same day as a hospitality firm's earnings announcements are made by nonhospitality firms, an average of 373.8 announcements of the total 380 announcements that occur on the same day as the typical hospitality earnings announcement. The remaining 6.2 announcements on average come from other hospitality firms, 4 of them from other subsectors and 2.2 from within the same subsector. Although they are small in number, earnings announcements from other hospitality firms may have an outsize impact on the trading in hospitality stocks if they draw attention to hospitality stocks in general or if they provide information that enhances investors' ability to interpret another hospitality firm's news.
Exhibit 4:

Number of Other Earnings Announcements per Event Day, by Category.

\begin{tabular}{lccc}
\hline & $M$ & Median & SD \\
\hline All other earnings announcements & 380.0 & 368 & 226.0 \\
Nonhospitality earnings & 373.8 & 363 & 222.5 \\
$\quad$ announcements & & & \\
Other hospitality earnings announcements & & \\
All & 6.2 & 5 & 4.7 \\
Outside of subsector & 4.0 & 3 & 3.6 \\
Within subsector & 2.2 & 2 & 2.3 \\
\hline
\end{tabular}

Note. The sample includes 159 hospitality stocks and their collective 3,709 earnings announcements from 1999 through 20I I. Table displays the mean, median, and standard deviation of the number of other earnings announcements, by category, across all stock/earnings announcement days.

\section{Earnings Surprises}

We define the earnings surprise for a stock as follows. We take the difference between the stock's announced earnings and the mean of recent analyst forecasts preceding the announcement and divide the result by the stock price. ${ }^{4} \mathrm{We}$ use the mean of recent analyst forecasts because combination forecasts are generally less noisy than a single forecast (e.g., Brown and Caylor 2005) and better represent the definition of earnings surprise.

\section{Abnormal Volume and Abnormal Return}

To examine how earnings announcements affect the trading volume and returns of stocks above and beyond their typical trading activity, we measure "abnormal" trading volume and returns after adjusting for the typical trading activity for each stock. We follow the literature in calculating the abnormal volume by adjusting for a stock's yearly average (e.g., Malmendier and Shanthikumar 2007). We calculate abnormal volume as the ratio of a stock's trading volume (in shares) on each earnings announcement date to the stock's average daily trading volume in the same year (excluding earnings announcement dates in that year), minus one. For example, if a stock typically has trading volume of 1,000 shares per day on non-announcement days and has volume of 1,500 shares on an earnings announcement day, its abnormal volume is defined as $1,500 / 1,000-1=50 \%$.

We calculate the abnormal return for a stock as the stock's return minus the CRSP value-weighted market return on the same day, as is typical in the literature (e.g., Begley and Fischer 1998). For example, if a stock's return on its earnings announcement day is 1 percent and the market return on the same day is 0.75 percent, the stock's abnormal return is defined as $1 \%-0.75 \%=0.25 \%$. 


\section{Empirical Methodology}

The central question of this paper is how a hospitality stock's reaction to its earnings announcement is affected by other firms' announcing earnings on the same day. Our first regression equation models the reaction of the hospitality stock's volume to other earnings announcements, controlling for the surprise in its own announcement, as follows ${ }^{5}$ :

$$
\begin{aligned}
\text { Volume }_{i, t, t+1}=\alpha & +\beta_{1} \text { EarningsAnnouncements }_{t, t+1}^{\text {Other }} \\
& +\beta_{2} \text { AbsoluteSurprise }_{i, t}+\varepsilon_{i, t},
\end{aligned}
$$

where $i$ refers to the hospitality stock of interest and $t$ refers to the date of the hospitality stock's earnings announcement. Volume ${ }_{i, t, t+1}$ is the abnormal volume of stock $i$ during the two-day period of the earnings announcement (days $t$ and $t+1) ; \alpha$ is a constant; EarningsAnnouncements ${ }^{\text {Other }}{ }_{t, t+1}$ is the number of other earnings announcements on days $t$ and $t+1$; AbsoluteSurprise ${ }_{i, t}$ is the absolute value of the earnings surprise for stock $i$ on day $t$; and $\varepsilon_{i, t}$ is the error term.

We use the absolute value of the earnings surprise in Equation 1 because both positive and negative surprises (i.e., a firm announcing earnings either above or below analysts' consensus forecast) would be expected to lead to higher volume. All of the explanatory variables are standardized (by subtracting the variable's mean and dividing by its standard deviation), so coefficient estimates indicate the change in volume for a one standard deviation change in the explanatory variable. We conduct inference in this and all subsequent regressions using standard errors that are robust to both crosssectional correlation and idiosyncratic time-series persistence (double-clustered standard errors, as in Thompson 2011).

Our second regression equation, to model the reaction of returns to earnings surprises and other earnings announcements, must take into account the directional aspects of returns. Logically, a positive earnings surprise would be expected to lead to a positive abnormal return, and a negative earnings surprise would be expected to lead to a negative abnormal return. If other earnings announcements occurring on the same day cause a distraction for investors, we would expect to see abnormal returns that are smaller in magnitude in either direction. We thus model the relation between a hospitality stock's return and other earnings announcements, controlling for the surprise in its own announcement, as follows:

$$
\begin{aligned}
\text { Return }_{i, t, t+1}=\alpha & +\beta_{1}\left(\begin{array}{l}
\text { EarningsAnnouncements }_{t, t+1}^{\text {Other }} \\
\times \text { PosNeg }_{i, t}
\end{array}\right) \\
+ & \beta_{2} \text { Surprise }_{i, t}+\varepsilon_{i, t},
\end{aligned}
$$

where $i$ refers to the hospitality stock of interest and $t$ refers to the date of the hospitality stock's earnings announcement. Return $_{i, t, t+1}$ is the abnormal return of stock $i$ during the two-day period following the earnings announcement (days $t$ and $t+1$ ); $\alpha$ is a constant; Earnings Announcements ${ }^{\text {Other }}{ }_{t, t+1}$ is the number of other earnings announcements on days $t$ and $t+1$; PosNeg $_{i, t}$ is an indicator variable taking the value +1 if the earnings surprise for stock $i$ on day $t$ is positive and -1 if it is negative; Surprise ${ }_{i t}$ is the earnings surprise for stock $i$ on day $t$; and $\varepsilon_{i, t}$ is the error term. The use of the positive/negative indicator variable $\left(\right.$ PosNeg $\left._{i,}\right)$ captures the directional aspect of returns, so a negative value of the coefficient $\beta$ indicates that returns are smaller in magnitude (less positive for positive earnings surprises and less negative for negative earnings surprises) when other firms announce earnings on the same day. All of the explanatory variables are standardized in the same way as in the volume regressions, so coefficient estimates indicate the change in return for a one standard deviation change in the explanatory variable.

\section{Results}

In this section, we first present our results for how other earnings announcements affect a stock's trading volume and return on its own earnings announcement day. We then examine to what extent the within-industry effects are related to attention constraints (investor focus) versus the richer information environment provided by multiple hospitality stocks announcing their earnings. Finally, we investigate whether investor distraction on days with multiple earnings announcements leads to higher post-earnings announcement drift. Robustness checks are summarized at the end of this section.

\section{Volume Results}

Our first question is how the volume of trading in a hospitality stock on its earnings announcement day is affected by other firms announcing their earnings on the same day. Exhibit 5 presents the results from estimating regression Equation 1 with various subsets of other earnings announcements for our panel of 159 hospitality stocks over thirteen years.

Since the explanatory variables are standardized, their coefficients indicate the change in volume for a one-standarddeviation change in the explanatory variable. When earnings announcements by other stocks increase by one standard deviation, the abnormal volume for a hospitality stock decreases by about 6 percent on its earnings announcement date (coefficient of -0.0611 with a $p$-value of .0463 , see Specification 1 in Exhibit 5). This finding is consistent with the hypothesis that multiple earnings announcements on the same day distract investors from the news contained in each individual announcement. A richer story emerges in Specification 2, which reveals that while nonhospitality stock announcements are distracting, a cluster of hospitality stock announcements increases investors' focus. A one-standarddeviation increase in the number of nonhospitality 
Exhibit 5:

Volume Regressions.

\begin{tabular}{|c|c|c|c|}
\hline & Specification I & Specification 2 & Specification 3 \\
\hline All other earnings announcements & $-0.061 \mathrm{I} * *(.0463)$ & & \\
\hline Nonhospitality earnings announcements & & $-0.1078 * *(.0269)$ & $-0.1204 * *(.0145)$ \\
\hline \multicolumn{4}{|l|}{ Other hospitality earnings announcements } \\
\hline All & & $0.1502 * *(.0362)$ & \\
\hline Outside of Subsector & & & $0.0474(.3689)$ \\
\hline Within Subsector & & & $0.1732 * * *(.0040)$ \\
\hline Absolute earnings surprise & $0.6769 *(.0822)$ & $0.6762 *(.0818)$ & $0.681 \mathrm{I} *(.0808)$ \\
\hline Constant & $1.0231 * * *(.0000)$ & $1.0232 * * *(.0000)$ & $1.023 * * *(.0000)$ \\
\hline Observations & 3,709 & 3,709 & 3,709 \\
\hline Adjusted $R^{2}$ & 0.0231 & 0.0234 & 0.0237 \\
\hline
\end{tabular}

Note. The sample includes 3,709 earnings announcement events for 159 hospitality stocks from 1999 through $201 \mathrm{I}$. Dependent variable is the Abnormal Volume for a hospitality stock on the day of its earnings announcement and the following day. All the explanatory variables are standardized, so the coefficient estimate reflects the change in abnormal volume for a one-standard-deviation change in the explanatory variable. All Other Earnings Announcements is the number of other firms announcing earnings during the same two-day period. Nonhospitality Earnings Announcements is the number of nonhospitality firms announcing earnings during the same two-day period. Other Hospitality Earnings Announcements-All is the number of other hospitality firms announcing earnings during the same two-day period. Other Hospitality Earnings Announcements-Outside of Subsector is the number of hospitality firms from other hospitality subsectors announcing earnings during the same two-day period. Other Hospitality Earnings Announcements-Within Subsector is the number of other hospitality firms from the same hospitality subsector announcing earnings during the same two-day period. Absolute Earnings Surprise is the absolute value of the earnings surprise contained in the dependent variable stock's earnings announcement. $p$-Values (reported in parentheses next to the coefficient estimates) are based on standard errors that are robust to cross-sectional correlation and idiosyncratic time-series persistence.

Significance levels are also indicated by stars next to coefficient estimates as follows: *10\%. **5\%. $* * * 1 \%$.

announcements decreases the abnormal volume of a hospitality firm by 10.78 percent (coefficient on Nonhospitality Earnings Announcements is -0.1078 with a $p$-value of .0269). In contrast, a one-standard-deviation increase in the number of hospitality announcements increases volume by 15.02 percent (coefficient on All Other Hospitality Earnings Announcements is 0.1502 with a $p$-value of .0362). This result suggests that announcements by firms within the hospitality industry serve to increase investor focus on the hospitality sector or enhance investors' ability to interpret news through a richer information environment. Finally, the analysis shown in Specification 3 further separates the other hospitality earnings announcements into those by firms from other subsectors (Outside of Subsector) versus those from within the firm's subsector (Within Subsector). ${ }^{6}$ Announcements made by firms within a firm's own subsector have the greatest impact, with a higher and significant positive coefficient on the number of Within Subsector earnings announcements.

\section{Return Results}

We next turn to the impact of multiple earnings announcements on a stock's price reaction to the news of its own earnings announcements. Exhibit 6 presents the results from estimating regression Equation 2 with various subsets of other earnings announcements for our panel of hospitality stock earnings announcements.
Specification 1 of Exhibit 6 shows that other earnings announcements in general cause investor distraction. Abnormal returns are smaller in magnitude when there are more earnings announcements competing for investors' attention. The coefficient of -0.00132 on All Other Earnings Announcements indicates that a one-standard-deviation increase in the number of other earnings announcements reduces a hospitality stock's return by 0.132 percent, or 13.2 basis points, with a $p$-value of .0000 . As in the volume regressions, this overall negative relationship is driven by the nonhospitality earnings announcements. Specification 2 shows that when earnings announcements are separated into those of nonhospitality firms and other hospitality firms, the Nonhospitality Earnings Announcements have a negative coefficient $(-0.00567$, or -56.7 basis points per one-standard-deviation increase, with a $p$-value of .0459), while All Other Hospitality Announcements have a positive coefficient $(0.00575$, or 57.5 basis points per one-standard-deviation increase, with a $p$-value of .0080). These findings suggest that hospitality announcements bring investor focus to other hospitality stocks and exacerbate their price reactions to earnings news. Within the hospitality sector, announcements by firms within the same subsector contribute the most (in terms of magnitude and significance) to this focusing effect (see Specification 3).

Taken together, these results for volume and returns paint a picture of attention-constrained investors who nonetheless glean valuable information from corporate earnings announcements. When a hospitality firm announces its 


\section{Exhibit 6:}

Return Regressions.

\begin{tabular}{lcrc}
\hline & Specification I & Specification 2 & Specification 3 \\
\hline All other earnings announcements & $-0.00132^{* * *}(.0000)$ & & $-0.00585^{* *}(.0353)$ \\
Nonhospitality earnings announcements & & $-0.00567^{* *}(.0459)$ & \\
Other hospitality earnings announcements & & $0.00575^{* * *}(.0080)$ & $0.00340^{*}(.0733)$ \\
$\quad$ All & & & $0.00423^{* *}(.0136)$ \\
$\quad$ Outside of subsector & & $0.00285^{* *}(.0460)$ \\
$\quad$ Within subsector & $0.00281^{*}(.0513)$ & $0.00278^{*}(.0585)$ & $-0.00241(.2091)$ \\
Earnings surprise & $-0.00251(.2431)$ & $-0.00247(.2254)$ & 3,709 \\
Constant & 3,709 & 3,709 & 0.0309 \\
Observations & 0.0280 & 0.0305 & \\
Adjusted $R^{2}$ & & & 0.0309 \\
\hline
\end{tabular}

Note. The sample includes 3,709 earnings announcement events for 159 hospitality stocks from 1999 through 20II. Dependent variable is the Abnormal Return for a hospitality stock on the day of its earnings announcement and the following day. All explanatory variables are standardized, so the coefficient estimate reflects the change in abnormal return for a one standard deviation change in the explanatory variable. All Other Earnings Announcements is the number of other firms announcing earnings during the same two-day period. Nonhospitality Earnings Announcements is the number of nonhospitality firms announcing earnings during the same two-day period. Other Hospitality Earnings Announcements-All is the number of other hospitality firms announcing earnings during the same two-day period. Other Hospitality Earnings Announcements-Outside of Subsector is the number of hospitality firms from other hospitality subsectors announcing earnings during the same two-day period. Other Hospitality Earnings Announcements-Within Subsector is the number of other hospitality firms from the same hospitality subsector announcing earnings during the same two-day period. Earnings Surprise is the earnings surprise contained in the dependent variable stock's earnings announcement. $p$-Values (reported in parentheses next to the coefficient estimates) are based on standard errors that are robust to cross-sectional correlation and idiosyncratic time-series persistence.

Significance levels are also indicated by stars next to coefficient estimates as follows: *10\%. **5\%. *** $1 \%$.

earnings on the same day as many nonhospitality firms, investor distraction typically leads to lower volume and smaller price moves in response to the hospitality firm's news. But when a hospitality firm releases news on the same day as other hospitality firms, especially those in the same subsector, the richer news environment attracts investor focus and contributes to a larger reaction in terms of trading volume and returns.

\section{Attention versus Information}

There are two possible explanations for the finding that when more hospitality stocks announce earnings on the same day, the return reactions of announcing stocks are larger. Perhaps the additional earnings announcements draw investor attention to the hospitality sector (the focus channel), or perhaps the information contained in other announcements helps investors better interpret the information contained in each individual stock's announcement (the information channel). ${ }^{7}$ To disentangle these two explanations, we divide earnings announcements into those that contain new information (earnings surprises) and those that do not contain new information (no earnings surprises). If the presence of other hospitality earnings announcements affects returns through the information channel, only those announcements that contain earnings surprises should be significant. If, on the other hand, other hospitality earnings announcements affect returns through the focus channel, all announcements (both surprising and unsurprising) should be significant. Exhibit 7 presents the results from estimating regressions similar to Equation 2, separating the number of other hospitality earnings announcements according to whether they have earnings surprises.

Overall, the picture that emerges from Exhibit 7 supports the interpretation that other hospitality earnings announcements draw investor focus to the sector. Specification 1 shows that both surprising and unsurprising announcements have an impact on returns. Coefficient estimates on All Others: Surprises and All Other: No Surprises are positive and significant. If the return effect were driven entirely by the richer information environment, we would expect only those other earnings announcements containing information (i.e., earnings surprises) to be significant. Similarly, Specification 2 shows that in the Outside of Subsector and Within Subsector categories, both surprising and unsurprising earnings announcements have similar effects on returns. Although the coefficient estimates and significance levels vary in some surprise/no surprise pairs in Specifications 1 and 2, statistical tests (not reported) show that the differences are not statistically significant.

\section{Post-Earnings-Announcement Drift}

One implication of investor attention constraints is that if investors fail to fully incorporate the news in a stock's earnings surprise on the day that earnings are announced, the 


\section{Exhibit 7:}

Return Regressions: With and Without Earnings Surprises.

\begin{tabular}{lcc}
\hline & Specification I & Specification 2 \\
\hline $\begin{array}{l}\text { Nonhospitality earnings announcements } \\
\text { Other hospitality earnings announcements }\end{array}$ & $-0.00570^{* *}(.0438)$ & $-0.00585^{* *}(.0326)$ \\
$\quad$ All other: Surprises & $0.00485^{* *}(.0124)$ & \\
All other: No surprises & $0.00629 * * *(.007 I)$ & $0.00287(.1036)$ \\
$\quad$ Outside of subsector: Surprises & & $0.00394 *(.0958)$ \\
$\quad$ Outside of subsector: No surprises & & $0.00418 * *(.0365)$ \\
$\quad$ Within subsector: Surprises & & $0.00496 * *(.024 I)$ \\
$\quad$ Within subsector: No surprises & $0.00285 *(.0536)$ & $0.00279 * *(.0437)$ \\
Earnings surprise & $-0.00243(.2468)$ & $-0.00241(.2134)$ \\
Constant & 3,709 & 3,709 \\
Observations & 0.0316 & 0.0330 \\
Adjusted $R^{2}$ & & \\
\hline
\end{tabular}

Note. The sample includes 3,709 earnings announcement events for 159 hospitality stocks from 1999 through $201 \mathrm{I}$. Dependent variable is the Abnormal Return for a hospitality stock on the day of its earnings announcement and the following day. All explanatory variables are standardized, so the coefficient estimate reflects the change in abnormal return for a one standard deviation change in the explanatory variable. All Other Earnings Announcements is the number of other firms announcing earnings during the same two-day period. Nonhospitality Earnings Announcements is the number of nonhospitality firms announcing earnings during the same two-day period. Other Hospitality Earnings Announcements-All is the number of other hospitality firms announcing earnings during the same two-day period. Other Hospitality Earnings Announcements-Outside of Subsector is the number of hospitality firms from other hospitality subsectors announcing earnings during the same two-day period. Other Hospitality Earnings Announcements-Within Subsector is the number of other hospitality firms from the same hospitality subsector announcing earnings during the same two-day period. All Hospitality Earnings Announcement counts are further divided into those with earnings surprises (Surprises) and those without earnings surprises (No Surprises). Earnings Surprise is the earnings surprise contained in the dependent variable stock's earnings announcement. $p$-values (reported in parentheses next to the coefficient estimates) are based on standard errors that are robust to cross-sectional correlation and idiosyncratic time-series persistence.

Significance levels are also indicated by stars next to coefficient estimates as follows: *10\%. $* * 5 \%$. *** $1 \%$.

price of the stock will continue to move in the direction of the earnings surprise over the subsequent days and weeks, as the information is gradually incorporated into the stock's price. The phenomenon of stock prices continuing to move in the direction of earnings surprises (called post-earningsannouncement drift or PEAD) has been widely documented for the broad stock market and for hospitality stocks in particular. ${ }^{8}$ Our interest is in whether PEAD is related to investor distraction and investor focus. Our conjecture is that hospitality stocks with more competing earnings announcements and more nonhospitality earnings announcements would experience higher PEAD since they underreact on the day their earnings are announced. In contrast, we expect lower PEAD for hospitality stocks that announce with other hospitality stocks since they react more fully on the earnings announcement date.

In Exhibit 8, we present the results of regressions of longer-term abnormal returns on earnings surprises (calculated over twenty, forty, and sixty days after the earnings announcement, following the literature) and the number of other earnings announcements. Unfortunately, the signalto-noise ratio is quite weak in these regressions, as our sample is small and many other events can affect returns over these longer time periods. We find only weak evidence of a link between PEAD and the number of earnings announcements on a day. In Specification 2, the coefficient on
Nonhospitality Earnings Announcements is 0.00358 (with a $p$-value of .0847), suggesting that a one-standard-deviation increase in the number of nonhospitality earnings announcements increases the subsequent twenty-day return for a hospitality stock by 35.8 basis points $(0.358 \%)$. While most of the other coefficient estimates have the predicted signs (positive for All Other and Nonhospitality Earnings Announcements, negative for Other Hospitality Earnings Announcements), outside of Specification 2, none are statistically significant at the 10 percent level.

\section{Robustness Checks}

As a robustness check, we repeat all of our analyses for restaurant and hotel firms, which are the two largest subsectors. All of the coefficient estimates retain the same sign but many lose statistical significance because the small sample sizes erode statistical power. We examine the robustness of our results to using a one-day earnings announcement window and find similar results. All the results are robust to alternative specifications that use an interaction term between the number of earnings announcements and earnings surprises and to using decile rankings rather than actual values for the number of earnings announcements and for earnings surprises. To test for time variation in the focus and distraction effects, we include a time trend or year-fixed 


\section{Exhibit 8:}

Post-Earnings Announcement Drift Regressions.

\begin{tabular}{|c|c|c|c|c|c|c|}
\hline & \multicolumn{2}{|c|}{ Twenty-day Return } & \multicolumn{2}{|c|}{ Forty-day Return } & \multicolumn{2}{|c|}{ Sixty-day Return } \\
\hline & Specification I & Specification 2 & Specification 3 & Specification 4 & Specification 5 & Specification 6 \\
\hline $\begin{array}{l}\text { All other earnings } \\
\text { announcements }\end{array}$ & $\begin{array}{c}-0.00196 \\
(.1205)\end{array}$ & & $\begin{array}{c}-0.00405 \\
(.2952)\end{array}$ & & $\begin{array}{r}-0.00450 \\
(.3332)\end{array}$ & \\
\hline $\begin{array}{l}\text { Nonhospitality earnings } \\
\text { announcements }\end{array}$ & & $\begin{array}{l}0.00358^{*} \\
(.0847)\end{array}$ & & $\begin{array}{l}0.00552 \\
(.3495)\end{array}$ & & $\begin{array}{l}0.00192 \\
(.7859)\end{array}$ \\
\hline $\begin{array}{l}\text { Other hospitality earnings } \\
\text { announcements }\end{array}$ & & $\begin{array}{r}-0.00334 \\
(.106 \mathrm{I})\end{array}$ & & $\begin{array}{c}-0.00188 \\
(.7445)\end{array}$ & & $\begin{array}{r}-0.00329 \\
(.6345)\end{array}$ \\
\hline Earnings surprise & $\begin{array}{l}0.00314 \\
(.2396)\end{array}$ & $\begin{array}{l}0.00310 \\
(.2463)\end{array}$ & $\begin{array}{l}0.00627 \\
(.1016)\end{array}$ & $\begin{array}{l}0.00629 \\
(.1004)\end{array}$ & $\begin{array}{l}0.00662 \\
(.1502)\end{array}$ & $\begin{array}{l}0.00658 \\
(.1529)\end{array}$ \\
\hline Constant & $\begin{array}{l}0.00357 \\
(.1839)\end{array}$ & $\begin{array}{l}0.00358 \\
(.1820)\end{array}$ & $\begin{array}{l}0.00956^{* *} \\
(.0131)\end{array}$ & $\begin{array}{l}0.00955^{* *} \\
(.0132)\end{array}$ & $\begin{array}{l}0.01439 * * * \\
(.0019)\end{array}$ & $\begin{array}{l}0.01441^{* * *} \\
(.0019)\end{array}$ \\
\hline Observations & 3,709 & 3,705 & 3,709 & 3,709 & 3,709 & 3,709 \\
\hline Adjusted $R^{2}$ & 0.0259 & 0.0315 & 0.0214 & 0.0299 & 0.0200 & 0.0256 \\
\hline
\end{tabular}

Note. The sample includes 3,709 earnings announcement events for 159 hospitality stocks from 1999 through 201 I. Dependent variable is the Abnormal Return for a hospitality stock for twenty days (Specifications I and 2), forty days (Specifications 3 and 4), and sixty days (Specifications 5 and 6) beginning two days after the earnings announcement. All the explanatory variables are standardized, so the coefficient estimate reflects the change in abnormal return for a one-standard-deviation change in the explanatory variable. All Other Earnings Announcements is the number of other firms announcing earnings during the same two-day period. Nonhospitality Earnings Announcements is the number of nonhospitality firms announcing earnings during the same two-day period. Other Hospitality Earnings Announcements is the number of other hospitality firms announcing earnings during the same two-day period. Earnings Surprise is the earnings surprise contained in the dependent variable stock's earnings announcement. $p$-Values (reported in parentheses below the coefficient estimates) are based on standard errors that are robust to cross-sectional correlation and idiosyncratic time-series persistence.

Significance levels are also indicated by stars next to coefficient estimates as follows: * $10 \%$. $* * 5 \%$. *** $1 \%$.

effects in our regression equations. The coefficient estimates on the additional time terms are not statistically significant, and the coefficients on our variables of interest are not affected. In our return regressions (Equation 2), the effect of negative and positive earnings surprises is restricted to be symmetric. We also test an unrestricted model that allows for asymmetric reactions to positive and negative earnings surprises; the coefficient estimates for positive and negative surprises are not statistically significantly different. In a further refinement of our analysis of earnings announcements with surprises and those without (Exhibit 7), we find that congruent and divergent surprises have statistically indistinguishable effects.

\section{Implications and Limitations}

This study suggests that investors in hospitality stocks should pay attention to the number and type of earnings announcements surrounding their stocks of interest. Other studies have found that a stock's quarterly earnings announcement dates account for a substantial proportion of its price movement during the year. Numerous researchers find that a firm's quarterly earnings announcements contribute significantly to its stock price moves (e.g., Beaver 1968), and Ball and Shivakumar (2008) find that the proportion of information contributed by earnings announcements has risen in recent years. While these studies confirm that investors are wise to pay attention to the announcements made by firms in whose stocks they have an interest, our study takes this a step further. Earnings announcement calendars, which list the dates on which firms are expected to make their quarterly earnings announcements, are readily available on public websites as well as in the financial press. ${ }^{9}$ Our findings highlight that what matters is not only the announcement of the stock of interest but also the number and type of other firms announcing earnings on the same day. If there are many nonhospitality stocks announcing earnings on the same day, an investor is likely to find that a hospitality stock's price will underreact to its own news, leaving a greater opportunity to profitably trade on any earnings surprise. In contrast, a larger number of other hospitality firm announcements on the same day is likely to make stock prices move more quickly, reducing the window for profitable trading on news but also increasing market efficiency. More generally, being aware of how extraneous news can affect hospitality stock prices may help investors to manage their portfolios more efficiently.

Hospitality company executives may also find practical applications for these research findings. If executives' goal is to communicate clearly to investors and see their stock price efficiently reflect new information, they will likely benefit from announcing their earnings on days when fewer nonhospitality firms announce their earnings. They may also find it beneficial to cluster their announcements with other hospitality firms in their subsector. On the other hand, one could imagine that at some times executives would prefer 
that investors pay somewhat less attention to the firm's announcement (such as when the firm announces surprisingly low earnings), in which case executives may prefer to announce on a more crowded earnings announcement day. Firms can generally make changes to the day within a week on which they announce their earnings, which could complicate the search for a less or more crowded date if executives from many firms are pursuing a similar goal. Typically, a firm delaying its earnings announcement to much later in the quarter (not merely by a few days) is taken as a sign of bad news, as documented in Begley and Fischer (1998), among others.

The main limitation of this study is its relatively narrow focus on the hospitality industry. Our findings regarding the differential effects of earnings announcements from withinindustry versus other-industry firms may not hold for industries other than the hospitality sector. Previous work has shown that hospitality stocks often behave differently from other industries or the broad stock market. For example, Canina (1996) finds that hospitality initial public offerings exhibit better first-day and long-run performance than other initial public offerings, even after adjusting for their higher perceived risk. Goukasian, Ma, and Majbouri (2012) find that hotel stocks are more sensitive to monetary policy changes, and Weinbaum (2009) finds that hospitality firms time their stock issuances and repurchases better than firms from other industries. In our context, our results may not generalize to other industries if hospitality stocks are held by different types of investors, if the information environment for hospitality firms differs significantly from that of other industries, or if hospitality executives are more strategic in their timing decisions. We leave it to future research to explore the interplay of investor focus versus investor distraction in other industries.

\section{Acknowledgments}

The authors thank three anonymous referees, Jan Katz, Mike Lynn, and Gary Thompson; Bruce Tracey (the editor); and the participants in the Cornell Restaurant Working Group for helpful comments.

\section{Declaration of Conflicting Interests}

The author(s) declared no potential conflicts of interest with respect to the research, authorship, or publication of this article.

\section{Funding}

The authors declared the following financial support for the research, authorship, and publication of this article: The authors are grateful for financial support from the Institute of Social Sciences at Cornell University.

\section{Notes}

1. Esteban and Devesa (2011) present evidence that hospitality executives take steps to present their earnings in the best possible light.
2. Looking at the entire stock market, Hirshleifer, Lim, and Teoh (2009) find evidence consistent with earnings announcements acting as extraneous news events that can distract investors. They neither investigate the possible countervailing role of announcements from the same industry nor examine individual industries.

3. Of the 159 stocks in our sample, twenty-nine are present for the full thirteen-year sample period.

4. We define recent analyst forecasts as those issued since the last earnings announcement, as is typical in this literature; see, for example, Chakrabarty and Moulton (2012) and Hirshleifer, Lim, and Teoh (2009). Normalizing by the stock price is also the standard practice in this literature, as it adjusts for disparities in stock price across firms, and the percentage earnings surprise is more relevant to percentage returns.

5. We control for the surprise in each announcement because the extensive literature on earnings announcements finds that earnings surprises have a large impact on trading (see, for example, Fried and Givoly 1982).

6. For example, if the firm of interest is a restaurant company, announcements by other restaurant companies would be categorized as Within Subsector and announcements by hotels, airlines, gaming, and amusement parks would be categorized as Outside of Subsector.

7. Note that earnings surprises announced by other firms could enhance a firm's information environment whether the surprise is in the same or opposite direction as the firm's own surprise.

8. See, for example, Bernard and Thomas (1989) for a broad market analysis. Moulton and Wu (2012) show that PEAD occurs among hospitality stocks but tends to last for only forty days rather than the sixty days documented for the market as a whole.

9. See, for example, http://biz.yahoo.com/research/earncal/ today.html

\section{References}

Ball, Ray, and Lakshmanan Shivakumar. 2008. How much new information is there in earnings? Journal of Accounting Research 46:975-1016.

Barber, Brad M., and Terrance Odean. 2008. All that glitters: The effect of attention and news on the buying behavior of individual and institutional investors. Review of Financial Studies 21:785-818.

Beaver, William H. 1968. The information content of actual earnings announcements. Journal of Accounting Research 6:67-92.

Begley, Joy, and Paul E. Fischer. 1998. Is there information in an earnings announcement delay? Review of Accounting Studies 3:347-63.

Bernard, Victor L., and Jacob K. Thomas. 1989. Post-earningsannouncement drift: Delayed price response or risk premium? Journal of Accounting Research 27 (Supplement): 1-48.

Brown, Lawrence D., and Marcus L. Caylor. 2005. A temporal analysis of thresholds: Propensities and valuation consequences. Accounting Review 80:423-40.

Busemeyer, Jerome R., In J. Myung, and Mark A. McDaniel. 1993. Cue competition effects: Empirical tests of adaptive network learning models. Psychological Science 4:190-95. 
Canina, Linda. 1996. Initial public offerings in the hospitality industry: Underpricing and overperformance. The Cornell Hotel and Restaurant Administration Quarterly 37:18-25.

Chakrabarty, Bidisha, and Pamela C. Moulton. 2012. Earnings announcements and attention constraints: The role of market design. Journal of Accounting \& Economics 53:612-34.

Chakrabarty, Bidisha, Pamela C. Moulton, and Charles Trzcinka. 2013. Institutional holding periods. Working paper. Retrieved from http://papers.ssrn.com/sol3/papers.cfm?abstract_id=221 7588

Cherry, E. Colin 1953. Some experiments on the recognition of speech, with one and two ears. Journal of the Acoustical Society of America 25:975-79.

Corwin, Shane A., and Jay F. Coughenour. 2008. Limited attention and the allocation of effort in securities trading. Journal of Finance 63:3031-67.

DellaVigna, Stefano, and Joshua Pollet. 2009. Investor inattention and Friday earnings announcements. Journal of Finance 64:709-49.

Esteban, Laura P., and María Jesús Such Devesa. 2011. Earnings management in the Spanish hotel industry. Cornell Hospitality Quarterly 52:466-79.

Fried, Dov, and Dan Givoly. 1982. Financial analysts' forecasts of earnings. Journal of Accounting \& Economics 4:85-107.

Goukasian, Levon, Qingzhong Ma, and Mehdi Majbouri. 2012. The monetary policy risks of hospitality stocks. Cornell Hospitality Quarterly 53:339-46.

Hirshleifer, David, Kewei Hou, Siew H. Teoh, and Yinglei Zhang. 2004. Do investors overvalue firms with bloated balance sheets? Journal of Accounting \& Economics 38:297-331.

Hirshleifer, David, Sonya S. Lim, and Siew H. Teoh. 2009. Driven to distraction: Extraneous events and underreaction to earnings news. Journal of Finance 64:2289-325.

Hirshleifer, David, and Siew H. Teoh. 2003. Limited attention, information disclosure, and financial reporting. Journal of Accounting \& Economics 36:337-86.
Huberman, Gur, and Tomer Regev. 2001. Contagious speculation and a cure for cancer: A nonevent that made stock prices soar. Journal of Finance 56:387-96.

Malmendier, Ulrike, and Devin Shanthikumar. 2007. Are small investors naïve about incentives? Journal of Financial Economics 85:457-89.

Moulton, Pamela C., and Di Wu. 2012. Post-earningsannouncement drift in the hospitality industry. Cornell Hospitality Report 12:4-10 .

Peng, Lin. 2005. Learning with information capacity constraints. Journal of Financial and Quantitative Analysis 40:307-29.

Shefrin, Hersh, and Meir Statman. 1985. The disposition to sell winners too early and ride losers too long: Theory and evidence. Journal of Finance 40:777-91.

Sims, Christopher A. 2003. Implications of rational inattention. Journal of Monetary Economics 50: 665-90.

Stroop, J. Ridley 1935. Studies of interference in serial verbal reactions. Journal of Experimental Psychology 28:643-62.

Thompson, Samuel. 2011. Simple formulas for standard errors that cluster by both firm and time. Journal of Financial Economics 99:1-10.

Weinbaum, David. 2009. Assessing the historical performance of hospitality stocks: The investor's perspective. Cornell Hospitality Quarterly 50:113-25.

\section{Author Biographies}

Pamela C. Moulton, Ph.D., CFA, is an assistant professor at the Cornell University School of Hotel Administration. Her teaching and research interests include financial markets and market microstructure, with a special interest in the role of investors. Prior to her academic career, Moulton worked in research for more than a dozen years at various Wall Street investment banks.

Sarah Leow began work on this project while she was a student at the Cornell University School of Hotel Administration. She was graduated with honors in December 2012. 